\title{
A family support model for enhancing the well-being and work performance of Christians in managerial positions
}

\begin{tabular}{|c|c|}
\hline \multicolumn{2}{|c|}{$\begin{array}{l}\text { Authors: } \\
\text { Florence Matsveru' } \mathbb{} \\
\text { Johann-Albrecht Meylahn }{ }^{1} \text { — }\end{array}$} \\
\hline \multicolumn{2}{|c|}{$\begin{array}{l}\text { Affiliations: } \\
\text { }{ }^{1} \text { Department of Practical } \\
\text { Theology, Faculty of Theology } \\
\text { and Religion, University of } \\
\text { Pretoria, South Africa }\end{array}$} \\
\hline \multicolumn{2}{|c|}{$\begin{array}{l}\text { Research Project Registration } \\
\text { Project Leader: J.A. Meylahn } \\
\text { Project Number: } 02187133\end{array}$} \\
\hline \multicolumn{2}{|c|}{$\begin{array}{l}\text { Description: } \\
\text { Dr Matsveru is participating } \\
\text { in the research project, } \\
\text { 'Towards a practical } \\
\text { postfoundational theology as } \\
\text { public theology in response } \\
\text { to the challenges of lived } \\
\text { religion in contemporary } \\
\text { Southern Africa', directed by } \\
\text { Prof. Dr Johann Meylahn, } \\
\text { Department Practical } \\
\text { Theology, Faculty of Theology } \\
\text { and Religion, University of } \\
\text { Pretoria, South Africa. }\end{array}$} \\
\hline \multicolumn{2}{|c|}{$\begin{array}{l}\text { Corresponding author: } \\
\text { Johann-Albrecht Meylahn, } \\
\text { johann.meylahn@up.ac.za }\end{array}$} \\
\hline \multicolumn{2}{|c|}{$\begin{array}{l}\text { Received: } 22 \text { Mar. } 2018 \\
\text { Accepted: } 20 \text { June } 2018 \\
\text { Published: } 08 \text { Aug. } 2018\end{array}$} \\
\hline \multicolumn{2}{|c|}{$\begin{array}{l}\text { How to cite this article: } \\
\text { Matsveru, F. \& Meylahn, J-A., } \\
\text { 2018, 'A family support } \\
\text { model for enhancing the } \\
\text { well-being and work } \\
\text { performance of Christians in } \\
\text { managerial positions', HTS } \\
\text { Teologiese Studies/ } \\
\text { Theological Studies 74(1), } \\
\text { 4976. https://doi.org/ } \\
\text { 10.4102/hts.v74i1.4976 }\end{array}$} \\
\hline \multirow[b]{2}{*}{ 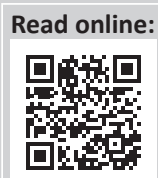 } & \\
\hline & $\begin{array}{l}\text { Scan this QR } \\
\text { code with your } \\
\text { smart phone or } \\
\text { mobile device } \\
\text { to read online. }\end{array}$ \\
\hline
\end{tabular}

This article is based on a PhD study entitled: 'Wellbeing and work performance of Christians in managerial positions: A Namibian case study'. The main aim of the study was to find out if there is a correlation between the well-being and work performance of Christian managers and support from their families, which would culminate into a model for use by Christian managers, Christian managers' families and Christian practitioners such as pastors, counsellors and other practitioners in the helping profession. The study was based on Don Browning's revised correlational approach to practical theology and used a mixed methods research design (quantitative and qualitative). Thirty-two Christian managers in Ohangwena Region, Namibia, participated in the study, and six biblical examples and other key scriptures were selected to draw theological principles related to Christian managers' well-being and work performance in relation to family support. The aim of this article is to present the model, which is based on the understanding that Christian managers' well-being affects their work performance, that family support contributes significantly to Christian managers' well-being, that Christian managers have a role to play if they are to receive family support, and that churches play an important part in encouraging family support for Christian managers.

\section{Introduction}

People in managerial positions appear to enjoy better remuneration and other material benefits than other workers (PwC 2013) and are therefore regarded highly and often looked up to for material and financial support. Being Christian adds to people's expectations and the Christian manager's personal sense of responsibility. Studies have shown that many people in managerial positions experience loneliness and high levels of stress because of their work (Portello \& Long 2001). Kunhiyop (2011:74) observes that African churches that are making an impact try to meet the real needs of people and suggests that as authentic theology listens to the voice of God, it must also listen to the issues from the context around it. This study endeavoured to listen to the holistic needs of Christian managers in a Namibian context and then to propose biblically inspired ways of enhancing their well-being and work performance. The proposed model may help Christian managers to cope better with their work and with life in general. The model can be used by Christian managers and their families at home and by pastors and counsellors in their ministry to Christian managers.

\section{Objective of the article}

The main objective of this article is to propose a model for use by Christian managers and their families and by pastors / counsellors to enhance the well-being and work performance of Christian managers.

\section{Theoretical framework}

This study was based on Browning's (1991) revised correlational approach, which Browning (1991:67) refers to as 'fundamental practical theology'. Browning presents fundamental practical theology as concerned with 'practice-theory-practice', as opposed to the theory-practice of Karl Barth and Paul Tillich (Browning 1991:43; Klaasen 2014). According to Browning (1991:7), fundamental practical theology begins with present theory-laden practice, then normative

Copyright: (C 2018. The Authors. Licensee: AOSIS. This work is licensed under the Creative Commons Attribution License.

Note: This article represents reworked aspects from the PhD dissertation of Florence Matsveru, titled, 'Wellbeing and work performance of Christians in managerial positions: A Namibian case study', prepared under the supervision of Prof. Dr Johann Meylahn, Department of Practical Theology, Faculty of Theology and Religion, University of Pretoria. 
theory-laden practice and results in more critically held theory-laden practices. The four movements of Browning's approach are (1) descriptive theology, which seeks to give 'a thick description of contemporary theory-laden practices' (Browning 1991:49); (2) historical theology, which 'confronts our praxis in the light of the normative texts that are already part of our effective history' (Browning 1991:49); (3) systematic theology, which examines 'the general themes of the gospel that respond to the general questions that characterize the situation of the present' (Browning 1991:51; Rowell, Fulkerson \& Lischer 2007:2); and (4) strategic practical theology, which focuses on action (Browning 1991:55, 57). Strategic practical theology is the most important movement for this article as it is the part that proposes a family support model to improve Christian managers' wellbeing and work performance.

Browning's approach has been criticised by some scholars such as Klaasen (2014:1-6), who is of the opinion that Browning reduces practical theology to theory or academics by absorbing practice into the theory. Another criticism is that Browning raises praxis above scripture (Rowell et al. 2007; Smith 2014). Dakin (1996:215) proposes a 'theological' practical theology rather than Browning's religious practical theology.

Although Browning has received criticism, his approach has been found to be helpful in some ways by the same critics and others because it is open, flexible and applicable to different theological settings (Dakin 1996; Meylahn 2010; Osmer 2008; Smith 2014), including African contexts. The researcher therefore found Browning's approach to be applicable to the topic under study.

The researcher found Osmer's (2008) four tasks to be helpful in pastoral intervention for Christian managers, as they are designed mainly for congregational studies. This is not a diversion from Browning's model, which informed the study, but a strengthening of it in the final stage (the strategic practical theology stage). How Osmer's tasks are used is explained in detail under 'Strategic practical theology: A model for family support for Christian managers'.

\section{Methodology}

Based on Browning's revised critical correlational approach, this study employed a mixed-methods approach (convergent model - quantitative and qualitative) whereby the researcher distributed questionnaires and interviewed people at the same time and then interpreted the data by comparing the results. This was done to strengthen the validity of the research, to clarify the results from one method with the results from the other method, to gain a richer and more indepth understanding of the population under study and to avoid researcher bias (Matsveru 2018:68).

Browning's four tasks of fundamental practical theology formed the framework of the study. The empirical part of the study placed greater emphasis on descriptive theology and, to a lesser extent, strategic practical theology, while the historical and systematic theology aspects jointly involved drawing theological principles from biblical examples and other Christian literature. Strategic practical theology was mainly covered in the formulation of a family support model for Christian managers. It should be noted that, for purposes of this article, the focus is on the family support model, which implies that the first three tasks of Browning's approach are only given in summary to put the model into perspective.

\section{Participants}

The study involved 32 Christian managers in Ohangwena Region, Namibia. St. Mary's Anglican Church, Odibo Parish (hereafter St. Mary's), and Four Square Gospel Church, Ohangwena (hereafter Four Square), who were purposefully selected as a starting point because of the relatively larger numbers of membership compared to many other churches in the region and their easier accessibility to the researcher. In addition, the researcher focused on Christian managers who regularly attended church to make it easier to distribute and collect questionnaires and to conduct interviews. Some participants from Four Square helped to further distribute the questionnaires to other qualifying Christian managers in the region, with the guidance of the researcher. The participants who opted for interviews were all married and had children. Males and females were almost equally represented in the study.

\section{Research instruments}

A questionnaire with both qualitative and quantitative questions was used for the (mostly) quantitative study and an interview guide for the qualitative study to cover the descriptive theology and (partially) strategic practical theology components of the study, while the Bible was mainly used to address the historical theology and systematic theology components, which were then examined in the light of the empirical findings to design the model to fully address the strategic practical theology component.

\section{Research procedure}

Willing participants were asked to indicate whether they preferred to complete the questionnaire or to be interviewed. The pastors of St Mary's and Four Square helped the researcher to distribute questionnaires to willing Christian managers who regularly attended their churches. The researcher asked some of the participants from Four Square to distribute the questionnaire to other qualifying Christian managers from other churches. Thirty-four questionnaires were distributed and 25 were completed, yielding a response rate of $74 \%$. Seven Christian managers from Four Square preferred interviews rather than the questionnaire. All seven were interviewed, thereby yielding a 100\% response rate in the interviews.

After the empirical study, the researcher studied six purposively selected leaders from the Bible (Adam, Joseph, 
Moses, David, Esther and Jesus) to draw relevant themes and principles.

The process led to the designing of a model for Christian managers, their families and Christian practitioners based on the findings, which forms the main part of this article.

\section{Descriptive theology (empirical findings) \\ Challenges faced by Christian managers and their impact on well-being and work performance}

The study found that although Christian managers love and appreciate their work, they also experience challenges at work, at home and at church by virtue of them being Christians and managers at the same time, which can affect their physical, emotional, psychological, spiritual and social well-being. In agreement with various scholars (Kittel 2016; Edward, Wick \& Paamar 2004; Oberholster 1993; Sherman \& Hendricks 1992; Sparks 2007a, 2007b; Werner 2008), the challenges experienced in these different settings include the following: (1) (work setting) conflicting worldviews, stress, unrealistic expectations, long working hours, handling difficult people, loneliness, time-management issues, problem-solving issues, tensions and jealousy; (2) (family setting) tensions because of family expectations, busy family life, stress, physical and emotional exhaustion, feeling overwhelmed, unsupported and unappreciated, worrying about the welfare of their families and how to avoid workfamily conflict; and (3) (church setting) lack of relevant teachings on applying God's word to their work, feeling under-utilised in the church and unrealistic expectations from the church.

\section{Importance of well-being for Christian managers' work performance}

Well-being was found to have serious effects on work performance by the majority of the participating Christian managers. The few participants who felt that well-being had little or no effect on work performance may have been intentionally suppressing thoughts, feelings and behaviours of the family domain as a strategy to avoid family-work conflict (Lambert 1990; Zimmerman et al. cited in Kuhlman \& Kuhlman 2004). Literature has also found that positive well-being improves job performance, commitment, morale and health in the workplace; that the well-being of managers affects the health of their organisations; and conversely that family conflict and poor relationships with family members hamper a person's work performance (Botha 2007; Chenoweth 2011; Cook \& Hunsaker 2001; De Sousa 2013; Frey \& Stutzer 2002; Kaiser 2007; MacLeod \& Clarke 2014:15). Žižek, Mulej and Milfelner (2017:56) concur that human beings '(in synergy) are physical, mental, social and spiritual entities' and Dooyeweerd (Faull 2012:512) adds that functioning poorly in any of these aspects negatively affects the whole person.
Well-being is therefore important for Christian managers' work performance. While there are many other interventions for improving well-being in different contexts, this study sought to see how family support can contribute.

\section{Importance of family support for Christian managers' well-being and work performance}

Although Christian managers appreciate the support they already receive from their families in the different areas of life (spiritual - which was ranked highest in the study, emotional, physical and material, social and psychological support), they wish their families could do more in the same areas, especially in the spiritual sphere. This is confirmed by a Fortune 500 survey, which found that Christian executives needed strong family relationships for their well-being (Truth for Today 1998:1). Most Christian managers depend on family support for their well-being and work performance. The few who depend little on family support have developed other self-motivating mechanisms. The importance of family support for Christian managers is confirmed in studies that have found that family circumstances contribute significantly to a manager's well-being and work performance (De Sousa 2013:109; Staude, as cited in Ajayi 2013:4; Van Horn 2007:6). Married managers have been found to need their spouses' support in order to maintain their well-being in the workplace (Groysberg \& Abrahams 2014).

The study found that there are problems associated with lack of family support for Christian managers, which include low sense of self in the workplace, lack of motivation or sense of purpose, lack of rest, lack of values, lack of guidance, loneliness, discouragement, stress, difficulties in workplace interactions, poor work performance and familywork conflict.

Christian managers' family support needs are holistic (spiritual, physical, emotional, psychological and social). This is in agreement with various other studies (Ajayi 2013:101; Groysberg \& Abrahams 2014). Curran's (1983) study found that healthy families have the following traits: communication and listening; affirming and supporting each other; mutual respect; a sense of trust; a sense of play and humour; a sense of shared responsibility; a strong sense of right and wrong; a strong sense of family, valuing time together as a family on important occasions such as birthdays, family gatherings and so on; a shared religious core; respect for each other's privacy; building each other's ability to make decisions; service to others; meal times and conversation, checking in with each other and sharing the events of their day; sharing leisure time; and seeking help with problems.

In agreement with the findings, various studies have revealed that family support is important in decreasing workplace stress, poor health, family-work conflict and work-related anxiety and in improving concentration at work, work performance, well-being and organisational commitment (Ajayi 2013; Balmforth \& Gardner 2006; Crittenden 2004; 
De Sousa 2013; Greenglass 1993; Greenhaus, Callanan \& Godshalk 2010; Michel et al. 2010; Noor 2004; Pitt-Catsouphes, Kossek \& Sweet 2006; Voydanoff 2004).

\section{Role of the Christian manager}

Christian managers are conscious that they should not be passive recipients of family support but that they also have a role to play. This includes communication of their needs, having the right attitude towards their families and supporting their families when needed. Mutual responsibility of family members relates with Bowen's view of the family as an 'emotional system' in which members need each other (cited in Becvar \& Becvar 2006:146).

\section{Involvement of the church}

The study also found that the church can play a significant role in enhancing mutual support between Christian managers and their families by teaching and preaching messages that are relevant to Christians in managerial positions (e.g. family, work, leadership, corruption in the workplace, integrity, dealing with difficult people), encouraging Christian managers to use their gifts and helping them to grow, providing libraries with relevant topics (e.g. leadership or raising children), forming relevant church groups, running leadership seminars, organising family outings, preaching on unity in the family, teaching children and families about the relationship between work and family, and offering relevant counselling services. Pastors and counsellors need to be trained and equipped to minister to Christians in managerial positions. Sherman and Hendricks (1992:16, 224-230) concur that the average person spends most of his or her life in the workplace, yet Christian teaching places little emphasis on the workplace and churches should provide Bible teaching and preaching that address specific workplace issues.

The empirical study has shown that Christian managers face a number of challenges, both common and unique. These challenges affect their spiritual, emotional, physical, psychological and social well-being, which may in turn affect their work performance. Family support can contribute immensely to the well-being of Christian managers and the church has a role to play in encouraging families to support Christian managers.

\section{Historical and systematic theology (biblical examples and principles)}

In line with Browning's approach to practical theology, after understanding people's experiences in descriptive theology, the sacred normative texts are consulted in historical and systematic theology (Browning 1991:6). The researcher consulted six biblical characters (Adam, Joseph, Moses, David, Esther, Jesus) and other relevant scriptural passages as examples from which to draw theological principles. Actual references to these characters are minimal in this article because the focus is on the principles drawn. Because of the wide gap between the contexts of the selected biblical characters and texts and those of Christian managers today, it is necessary to justify their use.

\section{Justification for selecting the six biblical characters}

Admittedly, using biblical examples to inform issues around the workplace, the family and the church can be problematic because of the chronological and contextual gap between the selected biblical characters and contemporary Christians in managerial positions. There is ongoing debate around using Old Testament narratives as examples for Christian life today. For example, Rogerson (2004:103-104) observes that the concept of work in the mainly agricultural settings of ancient Israel is totally different from the contemporary concept of work and argues that 'there is practically no point of contact between the workaday world of Old Testament times and our modern industrial and post-industrial situation'. Also, Rogerson (2004:30-31) finds the behaviour of some of the biblical leaders to be offensive in today's society because of cultural differences and therefore rightly warns against applying Old Testament narratives to today's world in an irresponsible manner. Similarly, Pietersen (2014) highlights the difficulties in using the Old Testament to inform Christian ethics because of the cultural gap between the Old Testament and contemporary life. Pietersen (2014:114) observes discrepancies within the biblical texts, which may not clearly show the biblical characters' values and outlook on life. However, Pietersen does not suggest impossibility but that with the correct understanding of context Old Testament narratives can be used responsibly as a source for Christian character today (Pietersen 2014:114). Lombaard (2003:438) lists the cultural gaps between the Old Testament world and our world as one of the reasons why the Old Testament enjoys little attention in reference to Christian spirituality, yet Lombaard (2003:438) suggests that those cultural gaps may actually be enriching.

Many Christians in leadership positions regard Bible personalities, especially Jesus, as their models for today's living (Ogletree cited in Pietersen 2014:100). For example, Werner's (2008:456) study on Christian SME ownermanagers in Germany and the UK found that the participants considered the popular question 'what would Jesus do?' as relevant in their day-to-day business dealings. In many African contexts, the Old Testament is much loved because of 'its close cultural and religious affinities with traditional African culture and ethnic religions' (Mojola 2014:1). Regardless of the historical, geographical, social, religious and cultural distance between the biblical narratives and African settings, these gaps have been bridged without difficulty because of the perceived link between African and 'biblical ontologies' (Mojola 2014:3; Mugambi cited in Getui, Maluleke \& Ukpong 2001). Mojola (2014:16) further argues that 'African interpretations of the Bible often become preoccupied with the search for resonance, rather than a quest for dissonance'. African interpreters therefore seem to focus more on what resonates with their audiences than what 
is controversial. Thus, Meyer and Pietersen (2016:244) have adopted the approach of Barton and Claassens, who regard biblical narratives as 'a moral reflection on the complications of life' in today's Christian ethics and that the narratives 'represent difficult situations where people struggled within a given society' (Pietersen 2014:9, 66). Apart from written studies, it is this researcher's observation that such a hermeneutic is very popular in African contexts. Many Old Testament narratives are therefore easily understood because of the perceived similarities with African experiences, and people tend to regard the narratives as practical examples for their personal lives. Kunhiyop's (2011) concurs that:

The political, economic, social, and religious concerns of Africa create fewer roadblocks in the reading and application of the Scripture than do those in more Western contexts. Africans are privileged to have this intimate relevance to the original context of the word of God. (p. 70)

As theologians seek to address people's real questions, it is important that they also answer real issues that people are asking (Kunhiyop 2011:67). This, however, does not mean that the gaps should be ignored but that biblical narratives are regarded by African theologians as relevant to today.

The Apostle Paul, who lived in New Testament times, writes that the experiences of the Old Testament patriarchs can be regarded 'as examples and were written down as warnings for us, on whom the fulfilment of the ages has come' (1 Cor 10:8-11). The biblical narratives therefore do offer examples from which norms and principles can be drawn to help Christians to assess their own moral conduct (Pietersen 2014:93).

In light of the above, the six biblical characters were purposively selected based on several factors that resonate with Christian managers. Although there is no perfect Old Testament or New Testament equivalent to Christian managers in the workplace, family or church, the following factors (with their contextual equivalents in brackets) were considered in the selection of the biblical characters: (1) they were all people of God (Christian); (2) they all were in some kind of leadership (managers); (3) they all had family members who are mentioned in the narratives (family), (4) whose actions or non-action may have had an impact on their lives either positively or negatively (family support or lack thereof); (5) they all faced some challenges in their lives (wellbeing); (5) they all had duties to perform in their leadership positions (work performance). Today's Christian managers can therefore learn from the biblical examples.

For lack of space, and also because this article focuses on the model, only a few examples and other scriptural references shall be picked under each subheading to draw some principles and lessons.

\section{Well-being and its effects on work}

The ancient Greek philosopher Aristotle described the wellbeing concept of $\varepsilon v ́ \delta \alpha \mu o v i ́ \alpha$ as simply referring to 'doing and living well' (Faull 2012:510). Although Aristotle argued that

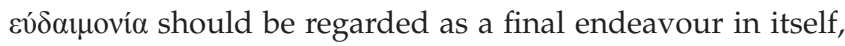
which should not be pursued for the sake of obtaining something else (Faull 2012:510), this study was based on the researcher's aim to see Christian managers' well-being resulting in improved work performance because how Christians perform in their workplaces will either glorify Christ or dishonour him (Luther as cited in Werner 2008:453). Physical, emotional, social, psychological and spiritual wellbeing is a concept that is supported biblically. Although the concept of suffering is inevitable for followers of Christ, especially those in leadership positions (Mt 16:24; Ac 14:22; 2 Cor 1:5; 1 Pt. 2:21-24; 4:13), most of these scriptures end with a comforting statement. The Bible seems to suggest that seeking well-being is not unbiblical, as long as Christians prioritise God's kingdom. For example, Matthew 6:33 instructs believers to seek first the kingdom of God and God will provide the necessities of life. France (cited in Blomberg 1992:83) argues that Matthew 6:33 is not 'decrying the body and its concerns as sordid and unworthy of our attention' but that believers should make their priorities right. Matthew 6:33 therefore shows that God cares about the well-being of believers. Another example is the Old Testament concept of

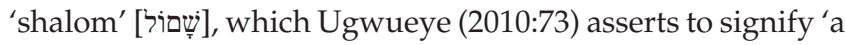
sense of well-being and harmony both within and outside, health, happiness, quietness of soul preservation, prosperity, tranquillity, security, safety, and it includes all that makes life worthwhile'. This implies a state of general well-being or wholeness. The word 'shalom' is used in the Old Testament $10 \%$ of the time as a greeting or farewell word, $25 \%$ of the time as a state of being free from conflict and $65 \%$ as referring to overall well-being and completeness (Charry as cited in Pennington 2015:n.p.). This overall well-being is desired by God for his people (cf. 2 Chr 15:15; Jr 33:6; Ps 85:8-12; 122:6-9). A New Testament equivalent of shalom is the Greek

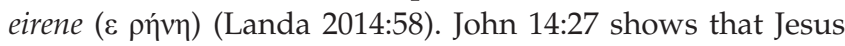
cared about his disciples' eirene: 'Peace I leave with you; my peace I give to you'.

The effects of well-being on performance are implied in the Bible. A good example is the observation of Jethro, Moses' father-in-law, regarding how Moses was performing his leadership duties:

The thing that thou doest is not good. Thou wilt surely wear away, both thou and this people that is with thee; for the thing is too heavy for thee, thou art not able to perform it thyself alone. (Ex 18:17-18, KJV)

The lesson here is that well-being can have a serious impact on a person's work. Jethro's advice has been used by many people in leadership positions - both religious and secular leaders (Melamed 2012:23). Likewise, Jesus shows the importance of well-being by withdrawing from the crowds with his disciples once in a while to refresh (Mk 6:31). AW Technologies, a Christian-based software company, have used Psalm 127:2 to formulate the principle that:

$[t]$ he amount of productivity you have when you are well rested, family/relationship situation is good, and generally happy is 
significantly higher than when you are tired, worn out, and fighting with your spouse ... [e]xecutives and managers need to know when to stop thinking they can do everything themselves (Asatryan et al. 2017:77).

This is a practical example of a company that has developed a biblical view on the importance of well-being for workplace performance, as well as the impact of the family situation on work.

Christian managers should therefore understand that their well-being can impact their work performance and that caring about their well-being is biblical.

\section{Importance of family support}

An overview of the Bible shows that the family played a significant role in enhancing the well-being and functioning of the people of God who were in leadership positions. This can be seen, for example, in Esther's request for Mordecai's support for her success with the king and how Mordecai's cooperation gave her the courage she needed to protect a whole nation. A number of principles can also be drawn from characters such as the very busy imaginary Proverbs 31 woman whose family appreciates and values her as she manages both the household and her outside work. Many have drawn principles for women from Proverbs 31 (cf. Biwul 2013; Sieg 2014). A Google search of 'Proverbs 31' produces thousands of hits to testify to this fact notwithstanding the growing literature looking for ways of empowering women and freeing them from the patriarchal burden portrayed in the Proverbs 31 wife to address contemporary gender-related social ills (Chitando 2004; Masenya 1996). The seemingly hidden statements that show approval, appreciation, value and support given (or that should be given) by this imaginary woman's family (husband and children) should come to the fore. In other words, the family responds to her efforts in a positive manner. Christian managers' families can therefore draw the principle of appreciating, valuing and believing in the Christian manager, to encourage him or her.

A seemingly controversial family-related passage is Jesus' statement in Matthew 10:34-38 (cf. Lk 14:26; 8:21), where Jesus seems to have come to destroy family ties. However, these passages cannot be read as if Jesus' mission is to divide families but that loyalty to him is of primary importance. Osiek (1996) concurs that Matthew 10:34-38 should be read:

... within the tradition of a higher loyalty to philosophy in Graeco-Roman context, and to God in Jewish intertestamental literature, where a fear is manifested that for the sake of familial affection, the clear-sighted will be seduced into security, softness, and betrayal of their higher truth. (p. 7)

Sim (2000:98-103) even suggests that the context of the passage, which is attested by Micah 7:6, is eschatological and refers to end time tribulation and martyrdom. Whether Matthew 10:34-38 is eschatological or refers to the Matthean era is not important in this case. What Osiek (1996) and Sim (2000) seem to be arguing against is using the passage to portray a violent Jesus. Such passages should therefore not be used as proof that Jesus regarded family as unimportant. Such an idea would be against other scriptures where Jesus taught his listeners to care for their families (e.g. Mt 15:3-6; Mk 7:10-12; Jn 19:25-27).

Family support for Christian managers is therefore important from a biblical perspective. This can be in the form of spiritual upliftment, practical help, appreciation, emotional and psychological care and social care as can be drawn from the preceding discussion.

\section{The role of the Christian manager}

From a biblical perspective, family support is mutual. The biblical characters surveyed in this study had a part to play in their families. An example is Joseph, who cared about the well-being of his brothers and attended to his family's needs (Gn 45). It is a biblical expectation for those in leadership to also consider their families' feelings and needs (1 Tm 5:8; 2 Cor 12:14; Mt 7:9-13; Gn 45:9-11;21-24; $47: 12$ ); to live in harmony with their families (Ephesians $6: 1-4)$; to create a positive family environment through prayer, reading God's word and serving God together (Dt 6:4-9; 2 Sm 7:18-29; 2 Chr 20:13; Jos 24:15; Ac 10:2); to accept their families' suggestions and advice ( $\operatorname{Pr} 1: 8)$; and to develop themselves ( $\operatorname{Pr} 15: 20 ; 1$ Tim 3:2-5). These are principles that Christian managers can apply. Also, Christian managers should learn to manage their finances well, not only for their own benefit but also for the benefit of their families as depicted in the story of Joseph (Gn 47:13-27). An attitude of humility is encouraged for leaders throughout the Bible. Several passages in scripture relate good leadership with humility (Pr 11:2; 16:18; 29:23; Mk 9:33-35; Phlp 2:5-8; Jas 4:6; 1 Pt 5:5-6) and this humility should be extended to their families (1 Pt 3:7).

\section{The role of the church}

The church also has a significant role to play in the well-being of Christian managers. The church should teach Christian managers to take care of their families and, in turn, teach families to support Christian managers. Both the Old Testament and the New Testament have instances where families were urged to gather together to fellowship, worship, dine and work together as families. For example, many times Moses, as leader of Israel, would call the Israelites to come together as families to worship YHWH, to fellowship and eat together (Gn 45:9; Ex 12:21; Nm 1:18; 2:34). The New Testament church also had times when they would meet and break bread together in the homes of believers (Ac 2:46-47; 10:2). It is in such fellowshipping that families can learn from each other, and share their lives with each other. The family is an important institution in God's eyes (Gn 12:3; 28:14); therefore the church must also uphold the family and include it in its programmes as enumerated under Descriptive theology (empirical findings) in this article. 


\section{Strategic practical theology: A model for family support for Christian managers}

Having found that Christian managers have physical, emotional, psychological, social and spiritual well-being needs that are both common and unique, a model to enhance Christian managers' holistic well-being and work performance through family support may be helpful. The proposed model (Figure 1) involves Christian managers, families and the church. The model also borrows ideas from Osmer's (2008) four tasks of practical theology as discussed later.

Although the model was designed with Christian managers in mind, it can be adopted for other Christians who may need family support for their well-being.

\section{Explanation of the model}

In summary, the model suggests that Christian managers experience various challenges at work, at home and at church. The challenges that Christian managers face may result in them developing spiritual, physical, emotional, psychological and spiritual needs. Family support can play a major role in improving Christian managers' well-being and work performance, but the Christian managers also have a part to play if they are to receive such support. Lack of family support (in the form of spiritual, physical, emotional, psychological or social absence; negativity; or the wrong kind of support) may lead to dysfunctional well-being, which may in turn result in diminished work performance. Pastoral intervention may help to encourage family support for Christian managers and improve Christian managers' wellbeing and work performance. Osmer's four tasks may help pastors and counsellors in their intervention strategies.

Each of the boxes in the model is explained in more detail below. Although pastoral intervention is discussed separately, Christian managers or their families can follow those tasks as well.

\section{Christian managers' challenges}

Christian managers experience various challenges in the work environment. Family situations may contribute to workplace challenges. Christian managers' experiences at church may have an impact on how they cope with their challenges.

\section{Christian managers' needs}

The challenging experiences that Christian managers face may result in them developing certain needs. These needs can be felt in some or all spheres (spiritual, physical, emotional, psychological and/or social). Meeting or not meeting these needs will affect the Christian managers' well-being and work performance positively or negatively, respectively.

Because of the needs that arise from Christian managers' challenges, family support can play a vital role in improving Christian managers' well-being and work performance. Depending on their family situation, Christian managers can either have family support or lack family support, both of which can have an impact on the well-being of a Christian manager.

\section{Family support}

When a Christian manager has family support, his or her well-being is affected positively, which helps to improve work performance. Family support includes spiritual and moral support (e.g. prayer, reading the Bible together, encouraging going to church, worshipping together), physical and material (e.g. caring when sick, helping with house chores), emotional (e.g. helping to carry burdens by listening to workplace challenges and needs, words of appreciation), psychological (e.g. advice giving and

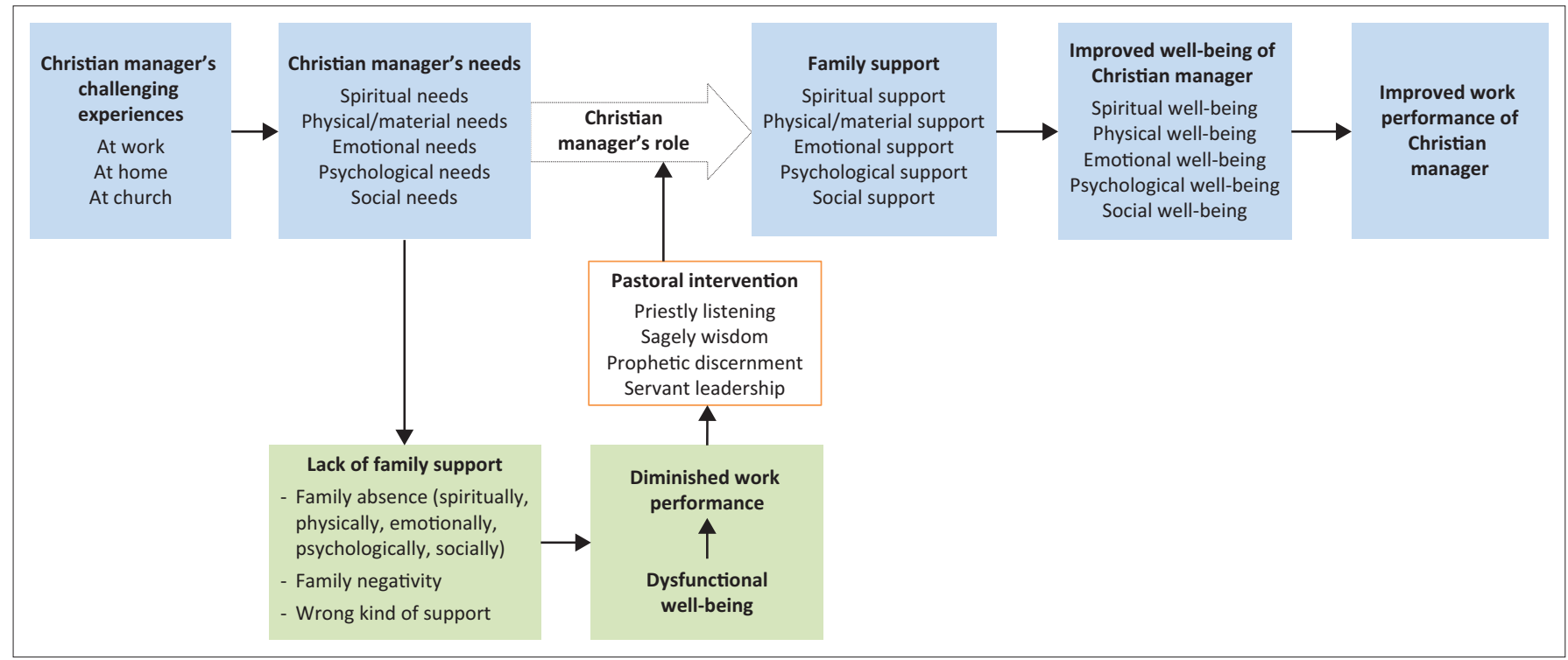

FIGURE 1: Christian managers' family support model. 
problem-solving) and/or social (e.g. spending time together and having fun times).

\section{Christian manager's role}

The Christian manager has a role to play in obtaining the needed family support for his or her well-being. Sometimes the Christian manager needs to communicate his or her challenges and needs to his or her family. Christian managers should have the right attitude towards their families (e.g. respect, humility). Instead of only expecting their families to support them, Christian managers also need to support their families when needed. Support is therefore mutual and the Christian manager cannot be a passive recipient of family support.

\section{Lack of family support}

If the Christian manager lacks family support, this can cause significant problems for the Christian manager. The problems that are likely to arise because of lack of family support can affect any or all spheres of the Christian manager's wellbeing (physical, emotional, psychological, social and spiritual). Lack of support can be in one or all of three forms.

\section{Family absence}

This is when the family either does not support the Christian manager at all or there is inadequate support as perceived by the Christian manager. They may be absent or unavailable spiritually (e.g. giving little attention to the spiritual life of the Christian manager, not praying for them or with them), physically (e.g. not caring when they are sick or tired), socially (e.g. not talking or having social moments with them) or emotionally (not concerned about how they feel). This means that the Christian manager is on his or her own.

\section{Negativity}

Here, the family is present but in a negative way (e.g. discouraging the Christian manager, refusing their requests, making negative comments or devaluing them).

\section{Wrong kind of support}

An example of wrong kind of support is giving wrong advice, giving support that is not needed or giving unbiblical support.

Lack of family support may lead to dysfunctional well-being (e.g. spiritual exhaustion, loneliness, stress, physical exhaustion, reduced trust, low self-esteem, etc.), which may in turn lead to diminished work performance. For example, discouraging comments may lead to a feeling of inadequacy, which may cause the Christian manager to struggle in dealing with subordinates as Christian leaders because of loss of a positive sense of self.

When the Christian manager's well-being becomes a concern, there may be need for pastoral intervention.

\section{Pastoral intervention}

The church (represented by pastors, counsellors or any other Christian person who plays a helping role) can play a major role in the well-being of Christian managers. Although pastors may align their teachings, sermons and other ministries to address the well-being of their congregants in the workplace, such teachings and ministries need to be informed by the needs of the congregants as indicated above. This does not imply reducing God's word to the individual needs of congregants but letting the Word of God speak into the real daily lives of people. Osmer's (2008) tasks of 'priestly listening', 'sagely wisdom', 'prophetic discernment' and 'servant leadership' are considered here in relation to pastoral intervention.

Although the model places pastoral intervention after dysfunctional well-being and diminished work performance, this does not mean that the church may only come in when the Christian managers present themselves with problems. Priestly listening can begin by showing interest in the lives of Christian managers even before there are observable problems. However, the model is intended to emphasise that Christian managers have family support needs that can be addressed at church level and pastors need to be prepared to give a listening ear to those needs. Also, the skills in the model can be used by the Christian managers or their family members to reflect on their own experiences and think about how they are affecting them and to strategise on the best family practices that will improve the well-being of Christian managers.

\section{Priestly listening (What is going on?)}

Priestly listening is Osmer's descriptive-empirical task, which involves gathering information that 'helps to discern patterns and dynamics in particular episodes, situations, or contexts' (Osmer 2008:4). Christian managers experience a range of challenges because of their status as Christians and as managers. While preaching is an important task of pastors, sometimes pastors can be caught up in 'telling' tasks without taking time to 'listen' to the challenges that Christian managers face in their day-to-day lives. Listening to these challenges and needs would help a pastor or counsellor to understand Christian managers and to help them better. Priestly listening helps the pastor or counsellor to discern patterns and dynamics around the Christian managers in their work and family situations in order to understand what is going on in their lives. This can be done on a one-on-one basis with a particular Christian manager or in forums designed for Christians in managerial positions, where Christian managers are afforded a platform to describe their experiences and challenges. Pienaar and Müller (2012) concur that a 'theology that allows for personal stories and takes them seriously, has the potential to be relevant and authentic, and therefore to be public theology'.

\section{Sagely wisdom (Why is this going on?)}

Osmer (2008:4) refers to this second task as the interpretive task. The pastor or counsellor may seek an understanding 
of the family dynamics of the Christian manager, which may help to better understand possible reasons why the Christian manager might be experiencing challenges. Instead of bringing his or her personal wisdom, the pastor or counsellor may need to have active conversation with the Christian manager to figure out possible reasons. This involves working with the Christian manager to look at what kind of family support, if any, the Christian manager receives and how the Christian manager relates to his or her family members. Although the pastor or counsellor may have an opinion, it is important that they hear the 'wisdom' or interpretation of the Christian manager, which will help the pastor or counsellor to then draw from existing theories and from his or her own knowledge, experience and understanding of such issues and to provide informed wisdom without disregarding the Christian manager's thinking.

\section{Prophetic discernment (What ought to be going on?)}

According to Osmer (2008), this normative task involves:

\begin{abstract}
... theological interpretation (using theological concepts to interpret particular episodes, situations, and contexts, informed by a theory of divine and human action), ethical reflection (using ethical principles, rules, or guidelines to guide action toward moral ends), and good practice (deriving norms from good practice, by exploring models of such practice in the present and past or by engaging reflexivity in transforming practice in the present). (pp. 139-161)
\end{abstract}

Here, the pastor or counsellor helps the Christian manager to see what God's word says about Christians in managerial positions, well-being, and work and family relations. Family members may be asked to participate. It may also involve asking the Christian manager what has worked before and what he or she has seen working for others in similar situations. For example, family members of Christian managers can be invited to participate in a Christian managers' forum to receive teachings together with the Christian managers. Generally, sermons and teachings may include topics that would address the Christian managers' challenges and needs, for example, caring for one another in the family; the importance of the family unit, work and family; how to behave as a Christian and a leader within the family; dealing with family-work conflict; how Christians in leadership positions should relate with their families; and so on.

\section{Servant leadership (How might we respond?)}

In this final step (the pragmatic task), the pastor or counsellor focuses on what can be done about the Christian manager's situation. According to Osmer (2008:4, 175-218), this step involves 'determining strategies of action that will influence situations in ways that are desirable and entering into a reflective conversation with the "talk back" emerging when they are enacted'. In other words, this is the strategic action plan for Christian managers and their families to ensure practical action based on the outcomes of the previous task. The pastor or counsellor may help Christian managers to draw up an action plan for themselves and their families or may encourage ongoing conversations between the Christian manager and family members. This step also includes ensuring that Christian managers and families are catered for in sermons, teachings, church groups and other church programmes, which should result in improving the wellbeing and work performance of the Christian managers, for the glory of God.

\section{Conclusion}

This article proposed a model for family support for Christian managers based on a study carried out in Ohangwena Region, Namibia, in 2016. The model considered the experiences of Christian managers and the needs that arise therefrom. Based on the findings, the model assumes that Christian managers' well-being affects their work performance and that family support is important in improving well-being and work performance. Moreover, the role of the church has been highlighted, borrowing from Osmer's four tasks of doing theology.

\section{Acknowledgements Competing interests}

The authors declare that they have no financial or personal relationships which may have inappropriately influenced them in writing this article.

\section{Authors' contribution}

F.M. is the author of this article, based on her PHD thesis under the supervision of J-A.M.

\section{References}

Ajayi, M.P., 2013, 'Work-family balance among women in selected banks in Lagos state, Nigeria', PhD thesis, Covenant University, Nigeria.

Asatryan, V.S., Henshell, T., Ellens, J. \& Frieswick, P., 2017, 'The building break: AW Technologies', Journal of Biblical Integration in Business 16(2), 72-78.

Balmforth, K. \& Gardner, D., 2006, 'Conflict and facilitation between work and family: Realizing the outcomes for organisations', New Zealand Journal of Psychology 35, 69-76.

Becvar, D.S. \& Becvar, R.J., 2006, Family therapy: A systemic integration, 6th edn., Pearson Education, Boston, MA.

Biwul, J.K., 2013: 'Reading the virtuous woman of Proverbs 31:10-31 as a reflection of the attributes of the traditional Miship woman of Nigeria', OTE 26(2), 275-297.

Blomberg, C.L., 1992, 'On wealth and worry: Matthew 6:19-34 - Meaning and significance', Criswell Theological Review 6(1), 73-89.

Botha, P.A., 2007, 'Development of a holistic wellness model for managers in tertiary institutions', PhD thesis, University of Pretoria.

Browning, D.S., 1991, A fundamental practical theology: Descriptive and strategic proposals, Fortress Press, Minneapolis, MN.

Chenoweth, D., 2011, Promoting employee well-being: Wellness strategies to improve health, performance and the bottom line, SHRM Foundation, Alexandria.

Chitando, E., 2004, "'The good wife": A phenomenological rereading of Proverbs 31:10-31 in the context of HIV/AIDS in Zimbabwe', Scriptura 86, 151-159.

Cook, C.W. \& Hunsaker, P.L., 2001, Management and organizational behavior, 3rd edn., McGrawhill/Irwin, New York.

Crittenden, A., 2004, If you've raised kids, you can manage anything: Leadership begins at home, Gotham Books, New York.

Curran, D., 1983, Traits of a healthy family, Winston Press, Minneapolis, MN

Dakin, T., 1996, 'The nature of practical theology repeating transformation: Browning and Barth on practical theology', Anvil 13(3), 203-221.

De Sousa, V.A.G.F., 2013, 'Family-work conflict, job satisfaction and burnout of working women with children', PhD thesis, University of Pretoria. 
Edward, R.E., Wick, A.C. \& Paarmar, B., 2004, 'Stakeholder theory and the corporate objective revisited', Organization Science 15(3), 364-369.

Faull, E., 2012, 'Christian religion and well-being', Scriptura 111(3), 509-519.

Frey, B.S. \& Stutzer, A., 2002, Happiness and economics: How the economy and institutions affect human well-being, University Press, Princeton, NJ.

Greenglass, E., 1993, 'Structural and social-psychological factors associated with job functioning by women managers', Psychological Reports 73, 979-986.

Greenhaus, J.F., Callanan, G.A. \& Godshalk, V.M., 2010, Career management, 4th edn., Sage, London.

Groysberg, B. \& Abrahams, R., 2014, 'Manage your work, manage your life', Harvard Business Review 92(3), 58-66.

Kaiser, L.C., 2007, 'Gender-job satisfaction differences across Europe: An indicator for labour market modernization', International Journal of Manpower 28(1), 75-94.

Kittel, T.D., 2016, Christianity and management: How you can become a successful Christian manager through servant leadership, (excerpt), viewed 03 February 2016, from http://www.buybooksontheweb.com/peek.aspx?id=1648

Klaasen, J.S., 2014, 'Practical theology: A critically engaged practical reason approach of practice, theory, practice and theory', HTS Teologiese Studies/Theological Studies 70(2), Art. 1950, 1-6. https://doi.org/10.4102/hts.v67i2.1950

Kuhlman, P.S. \& Kuhlman, G.A., 2004, Balancing family and work, viewed 03 February 2016, from http://www.stayhitched.com/balance.htm

Kunhiyop, SW., 2011, 'Challenges and prospects of teaching theology in Africa', SBJT 15(2), 64-76.

Lambert, S.J., 1990, 'Processes linking work and family: A critical review and research agenda', Human Relations 43, 239-257.

Landa, A., 2014, 'Shalom \& Eirene: The full framework for health care', Christian Journal for Global Health 1(1), 57-59.

Lombaard, C., 2003, 'The Old Testament in Christian spirituality: Perspectives on the undervaluation of the Old Testament in Christian spirituality', HTS 59(2), 433-450.

MacLeod, D. \& Clarke, N., 2014, The evidence: Wellbeing and employee engagement, Research report written on behalf of Engage for Success, viewed 03 July 2017 from http://www.engageforsuccess.org

Masenya, J.M., 1996, 'Proverbs 31:10-31 in a South African context: A Bosadi (womanhood) perspective', PhD thesis, University of South Africa.

Matsveru, F., 2018, 'Wellbeing and work performance of Christians in managerial positions: A Namibian case study', Unpublished PhD thesis, University of Pretoria.

Melamed, A., 2012, 'Jethro's advice in medieval and early modern Jewish and Christian political thought', Jewish Political Studies Review 2(1-2), 3-41.

Meyer, E. \& Pietersen, L., 2016, 'Old Testament stories and Christian ethics: Some perspectives from the narrative of Judah and Tamar', Stellenbosch Theological Journal 2(1), 241-259.

Meylahn, J.A., 2010, The church in the postmodern global village: Towards pastora redemptive communities, University of Pretoria, Pretoria.

Michel, J.S., Mitchelson, J.K., Pichler, S.M. \& Cullen, K.L., 2010, 'Clarifying relationships among work and family social support, stressors, and work-family conflict', Journa of Vocational Behavior 76, 91-104.

Mojola, A.O., 2014, 'The Old Testament or Hebrew Bible in Africa: Challenges and prospects for interpretation and translation', Verbum et Ecclesia 35(3), viewed 04 February 2018 https://doi.org/10.4102/ve.v35i3.1307

Noor, N.M., 2004, 'Work-family conflict, work and family-role salience, and women's well-being', Journal of Social Psychology 144(4), 389-405

Oberholster, B., 1993, Management - A Christian perspective, viewed 04 February 2016, from http://ict.aiias.edu/vol_12/12cc_229-243.htm
Osiek, C., 1996, 'The family in early Christianity: "Family values" revisited', The Catholic Biblical Quarterly 58, 24.

Osmer, R.R., 2008, 'Practical theology: A current international perspective', HTS Teologiese Studies/Theological Studies 67(2), viewed 16 July 2016, from https:// doi/10.4102/hts.v67i2.1058

Pennington, J., 2015, 'A biblical theology of human flourishing', Institute for Faith Work and Economics, viewed 04 June 2018, from http://tifwe.org

Pienaar, H.E. \& Müller, J.C., 2012, 'The practical theologian as decentred but influential facilitator', HTS Teologiese Studies/Theological Studies 68(2), Art. \#1307, 10 pages. https://doi.org/10.4102/hts.v68i2.1307

Pietersen, L., 2014, 'Using the Old Testament in Christian ethics: The story of Judah and Tamar', Master's thesis, University of Pretoria.

Pitt-Catsouphes, M., Kossek, E.E. \& Sweet, S., 2006, The work and family handbook: Multi-disciplinary perspectives and approaches, Erlbaum, Mahwah, NJ.

Portello, J.Y. \& Long, B.C., 2001, 'Appraisals and coping with workplace interpersonal stress: A model for women managers', Journal of Counseling Psychology 48(2), 144-156. https://doi.org/10.1037/0022-0167.48.2.144

PwC, 2013, Namibia and South African remuneration trends, viewed 08 June from http://www.pwc.co.na

Rogerson, J., 2004, Theory and practice in Old Testament ethics, T\&T Clarke International, London.

Rowell, A., Fulkerson, M.M. \& Lischer, R., 2007, 'Practical theology as a hermeneutical, moral enterprise: Browning's movements in practical theology', Th.D. seminar paper: Explorations in practical theology, viewed 13 February 2017 from www. paper: Exploration
andyrowell.net

Sherman, D. \& Hendricks, W., 1992, Your work matters to God, The Navigators, Telok Kurau.

Sieg, A., 2014, 'Understanding the wife of Proverbs 31', Senior thesis, Liberty University, US

Sim, D.C., 2000, 'The sword motif in Matthew 10:34', HTS 56(1), 84-104.

Smith, K.G., 2014, 'A fundamental practical theology: Don Browning', PowerPoint presentation, South Africa Theological Seminary, Johannesburg, South Africa, viewed 19 October 2016 from www.slideshare.net

Sparks, B.N., 2007a, 'A comparative evaluation of leadership in business and leadership in the Church to discover principles of Christ-like leadership that would help leaders lead effectively in any environment', Master's thesis, University of Pretoria.

Sparks, B.N., 2007b, 'The role of humility, servanthood, spirituality and values amongst business and church leaders in a South African context', Practical Theology in South Africa 23(2), 211-247.

Truth for Today, 1998, Building strong, happy Christian families, viewed 13 February 2016, from http://biblecourses.com

Ugwueye, L.E., 2010, 'Shalom (שָׁi)! A study of the concept of peace in the Old Testament', International Journal of Theology \& Reformed 2, 69-85.

Van Horn, A., 2007, 'A short introduction to subjective well-being: Its measurement, correlates and policy uses', Conference paper presented on 2-3 April 2007 University of Rome, Italy.

Voydanoff, P., 2004, 'The effects of work demands and resources on work-to-family conflict and facilitation', Journal of Marriage and Family 66(2), 398-412.

Werner, A., 2008, 'The influence of Christian identity on SME owner-managers' conceptualisations of business practice', Journal of Business Ethics 82(Springer), conceptualisations of business practice', Journal of Busin

Žižek, S., Mulej, M. \& Milfelner, B., 2017, 'Determinants of subjective emotional wellbeing and self-determination of employees: Slovene case', Naše gospodarstvo/ Our Economy 63(4), 54-65. 